\section{Conservation in a conflict area}

Illegal logging and the re-emergence of the conservation movement in Liberia

Liberia is slowly recovering from a 7-yearlong multifactional civil war in which at least 150,000 people were killed while countless others, fearful for their lives, fled the country. Families were divided and dispersed; many people are still traumatized by their experiences in the conflict. The country's infrastructure lies in ruins: many large towns have been destroyed; there is no mains electricity, no mains water and no postal service. Most schools are closed. For the majority of the country communication is poor or non-existent and many people are still hiding in the bush unsure whether it is safe to return to their towns and villages.

The country needs to rebuild itself. It needs food and clothing for immediate relief, money and building materials, seeds for farmers, resources to provide health care and education. Being perhaps the least deforested country in West Africa, one would expect that Liberia would at least have sufficient timber for its building needs. But there is scarcely any construction timber available because all the country's sawmills were destroyed in the war. Instead, logs are being cut and exported illegally to benefit expatriates, faction leaders and foreign entrepreneurs.

The situation now is fairly peaceful. A West African United Nations peace-keeping force has succeeded in providing security over much of the country and people are slowly returning to their abandoned homes and farms. In the cities people face the enormous task of rebuilding a shattered environment with pitifully few resources. Given these problems and almost unimaginable disorder, it is remarkable that the Society for the Conservation of Nature in Liberia (SCNL) has re-emerged and is eager to resume its conservation activities.

Although relatively small among African nations, Liberia contains the two most substantial blocks of closed canopy tropical rain forest within the Upper Guinean Forest block, a distinct zone recognized for its significant biodiversity and species endemism. In 1983 Sapo National Park, approximately 1300 sq $\mathrm{km}$ of rain forest in southern Liberia, was designated as Liberia's first national park, managed by the Division of Wildlife and National Parks of the Forestry Development Authority (FDA). The Society for the Conservation of Nature in Liberia was formed in 1996, and in 1987 it started a successful agricultural extension and public awareness programme around the park.

The civil war brought all of this activity to an end: park staff disappeared into the bush and the park headquarters was ransacked, as was the SCNL office in Monrovia and the headquarters of the FDA. For 6 years Sapo was abandoned. Since 1992, however, the USbased Society for the Renewal of Nature Conservation in Liberia (SRNCL), has been doing its best to monitor the situation. The SRNCL, was set up by a group of biologists from the USA and the Netherlands. It has raised funds and awareness and provided a safe haven in the US for Alex Peal, head of the Division of Wildlife and National Parks, who escaped with his family during the height of the civil war. In March and April this year the group visited Liberia to assess the situation and identify what could be done to re-establish SCNL and its activities at Sapo. The visit included a mission* to the Sapo area, which had been a focal point of factional fighting during the conflict. Towns and villages in the area had been largely destroyed and abandoned. It was encouraging to find that the park itself had been relatively unaffected, although the headquarters will require extensive repairs and vegetation regeneration had made the track to the research station impassable. Most of the species previously known to be in the park-including forest elephant, pygmy hippopotamus and Jentink's duiker were reconfirmed as present by local people.

*The mission included Henk Dop (The Netherlands), Reg Hoyt (Zoological Society of Philadelphia), Richard Nisbett (University of Oklahoma), Alexander Peal, Philip Robinson (University of California at San Diego) and James Walo (President of SCNL). 
Wildlife populations in and around the park may even have increased as a result of the dispersal of much of the human population - as indicated by complaints of damage to farming activities by wildlife, especially red river hogs, bushbuck and chimpanzees, and by large amounts of bush meat, predominantly black duikers, for sale along the main road of the area. People are slowly returning and preparing land for farming but there is a desperate shortage of seed rice and tools. No relief aid had yet reached the Sapo area but the team was welcomed by many people who were greatly reassured by the visit and enthusiastic about the possibility of the resumption of park activities. At one point during the visit a park ranger, not seen for 6 years, emerged from the bush in his uniform, ready to start work.

The really worrying discovery was evidence of illegal logging, although not apparently in the park itself. It had been reported that foreign entrepreneurs were working with local interests to open up logging roads and selectively remove high-value timber, taking advantage of the lack of enforcement capacity of the FDA, which has virtually no presence in the field. Throughout the war logs were exported illegally via the port of Buchanan and it is estimated that they would have generated millions of dollars. Now, although there is currently no officially licensed logging, it appears that foreign logging companies may be receiving concessions in compensation for losses of equipment during the war and that some factions may be controlling a substantial amount of logging activity.

The team observed logs being assembled at the port of Greenville, which is now being prepared to receive ships. Peace-keeping forces did not interfere with these illegal activities and there was no FDA presence, although the logs had false FDA marks. The source of the logs seen at Greenville is from forest along a $250-\mathrm{km}$ road built during the war between Greenville and Buchanan: the team observed evidence of large-scale logging operations along this road. A large logging camp has been constructed on the banks of the Cestos River and named Midway City for its location on the new road. The road passes through the
Krahn-Bassa Forest, which has been proposed by WWF/IUCN for consideration as a national park and which contains populations of endangered elephants, antelopes, primates and birds. Representatives of the European Commission (EC) are currently surveying the Cestos and Senkwen Rivers for the installation of all-season bridges, which, while aiding desperately needed relief efforts, may also (unintentionally) exacerbate the environmental destruction that is now occurring.

Prior to the conflict, work was under way to develop sustainable forestry programmes, but until political stability returns to Liberia there seems little hope of halting this uncontrolled theft of what could be a sustainable source of desperately needed income. The SRNCL is currently working to organize a temporary international moratorium on imports of timber from Liberia.

Liberia currently has an interim government, protected by peace-keeping forces until the presidential elections, planned for late May. There are two main candidates, former faction leader Charles Taylor and the Opposition Alliance leader Dr Cleetus Wotorson. The latter appears to have more sympathy with the conservation of biodiversity than the former. Thus, the outcome of the elections - if indeed they take place-could determine the fate of the people and the wildlife of the one of the least researched centres of biodiversity in the world.

Meanwhile, efforts are under way to help the SCNL and the Division of Wildlife and National Parks to regain their capacity, and to support Liberian conservationists who have courageously kept working throughout the war. Some funds have been acquired from IUCN-Netherlands and WWF-International to provide small stipends for key staff and re-establish a headquarters for SCNL. Fauna \& Flora International has already started with help for project fund applications to the EC relief operation. The EC is keen to get humanitarian aid to the people of the Sapo region, especially in the form of seed rice and tools, and is hoping that SCNL and park rangers will be able to act as a focal point for this in the region. Other project applications are 
being made for employment of excombatants in park restoration and community projects. The best outcome for the park and the people who live nearby would be the successful integration of humanitarian relief work, postconflict reconciliation, and the restoration of the park and its conservation, development and educational activities. Fauna \& Flora International is working together with SRNCL and friends of Liberia from around the world to help Liberian conservationists to secure the funds and assistance they need. Providing the outcome of the elections leads to a favourable environment for conservation activity, FFI will be seeking to carry out further research, conservation and capacity-building work in this neglected country.

Mike Appleton, FFI's Conservation Development Unit, and Jacqui Morris, Editor
Mike Appleton visited Liberia in April this year and is co-ordinating FFI's support for conservation in Liberia. This issue of Oryx includes an appeal for support for this programme.

\section{Farewell to Gary Meffe}

We are sorry to have to say farewell to Gary Meffe, who is taking up a new post as editor of Conservation Biology. We thank him for his thought-provoking contributions to Oryx over the last two-and-a-half years and wish him success in his new challenge.

In future issues we plan to feature a series of guest editorials from other conservationists in various parts of the world.

Jacqui Morris, Editor

\section{SAVANNAH PERSPECTIVE}

\section{Challenges}

\author{
Gary K. Meffe
}

The world of the conservation biologist is nothing if not challenging. Continually limited funding, a depressing litany of habitat and species losses, a burgeoning human population that does not seem to grasp the relevance or depth of our problems, and a complex natural world with few easy and clear answers are just a few of the challenges that we face daily. Despite that, we continue on, confident in the knowledge that we are doing the right thing and hopeful that the global situation will improve with our help. We have little choice but to forge ahead if we truly believe that what we are doing is correct and necessary, so we persevere against evermounting odds.

But challenges need not be discouraging; on the contrary, they can be positive experiences, providing the energy (and sometimes anger) to fuel the engines of progress in conservation, and they certainly can keep things lively and interesting. At the deepest personal level, challenges help to renew interest, stimulate individuals to new heights and open up new avenues of investigation. In that spirit, I have accepted a new challenge that necessitates bringing 'Savannah Perspective' to a close. This will be my last Oryx column, and my new challenge, the Editorship of Conservation Biology, will have begun as you read this. I leave Oryx with a touch of sadness, with fond memories of the last two-and-a-half years and 10 columns, and with renewed excitement at the many challenges that lie ahead for us all.

Before leaving you, I want to convey a few recent and critical challenges being met right now by conservation biologists in the USA. The US Endangered Species Act, called by Secretary of the Interior Bruce Babbitt the most visionary piece of environmental legislation' in the world, continues to come under attack by those who do not fundamentally appreciate either their place in Nature or the role of functioning ecosystems in their personal welfare. The Act is due (actually long overdue) to be reauthorized, and draft revisions of the legislation are being circulated by 